\title{
Review on the Effect of Moisture or Rain Fall on Crop Production
}

\author{
Takele Zike Geneti \\ Department of Agronomy, Crop Research process, Ethiopian Institute of Agricultural Research, Werer \\ Agricultural Research center, PO Box 2003, Addis Ababa, Ethiopia
}

\begin{abstract}
Rainfall is one of the primary factors affecting soil erosion and crop production under rain-fed agriculture. The review sought to quantify the effect of rainfall or moisture on crop production. The Rainfall distribution, amount and intensity as well as rain fall season was reviewed in relation to crop growth and development response., As research show the effect of drought on barley showed that, during the vegetative stage, water stress primarily reduced yields by a reduction in light interception arising from smaller leaves. However, for stress during the grain filling phase, yields were reduced almost equally by reduced photosynthesis per unit area arising from leaf senescence. The impact of rainfall on crop production can be related to its total seasonal amount or its intraseasonal distribution. In the extreme case of droughts, with very low total seasonal amounts, crop production suffers the most. But more subtle intra-seasonal variations in rainfall distribution during crop growing periods, without a change in total seasonal amount, can also cause substantial reductions in yields. This means that the number of rainy days during the growing period is as important, if not more, as that of the seasonal total. Generally, the effect of rainfall variability on crop production varies with types of crops cultivated, types and properties of soils and climatic conditions of a given area.
\end{abstract}

Keywords: Soil moisture, rain fall, crop adaptation and drought

DOI: $10.7176 / C E R / 11-2-01$

Publication date:March $31^{\text {st }} 2019$

\section{Introduction}

Dynamism of the crop, livestock, and natural resource components of the Ethiopian farming systems is governed by the size and distribution of rainfall. In a country where the entire rural population ekes a living out of the land through rain-fed agriculture, shortage of rain has a direct effect on the amount of available food. Even so drought is an important and common phenomenon in Ethiopia, punctuating the agricultural seasons of the country for centuries.

The importance of the negative risk of drought experienced virtually in all parts of Ethiopia cannot be overemphasized and indications are that it will be more frequent and more severe (Tesfahunetal., 2006; Zelekeet al., 2010). Historically, the unremitting droughts in the last three to four decades were considered synonymous to famine in Ethiopia. The longer the period of rain failure, the more widespread the food shortages. Vulnerable families become susceptible to malnutrition and disease. Malnutrition leads to undernourishment and the subsequent horrors of famine and deaths (Woldemariam, 1991). This, therefore, entails comprehensive investigation of drought risk perception and management. Sufficient understanding of the perceptions, the types, and management of drought risk is essential in developing strategies that can help farmers optimize their enterprises under uncertainty and risk conditions.

In a predominantly agricultural system, natural rainfall is the main source of water for agriculture sector in Ethiopia. This rain-fed based agriculture system is highly sensitive to spatiotemporal variability of rainfall. In areas where rainfall is limited, variable and unpredictable in space and time, water is the major limiting factor for crop production (Sivakumar, 1992). According to Simane and Struick, (1993), in addition to the amount of rainfall, its distribution in a given season is critical in affecting crop growth and its production.

Uneven seasonal distribution of rainfall can expose crops to different degrees of dry spells without significant reductions in total rainfall (Barron et al., 2003). Northern Ethiopia is the area most affected by climate variability and series of droughts and famine in the country.

More than a dozen localized and regional droughts happened in this area within the last three decades and affected agricultural productions negatively; and millions of rural poor farmers and their environment (Vste, et al., 2013). In a recent study of rain fed cereal potential under different climate change scenarios and varying rainfall, losses of rain fed production potential in the most vulnerable developing countries was predicted under most scenarios. Losses were estimated at $10 \%-20 \%$ of production area, with some 1-3 billion people possibly affected(Fischer and van 2002). In particular, Sub-Saharan Africa is estimated to lose $12 \%$ of its cultivation potential, mostly in the Sudan-Sahelian zone, which is already subject to high climate variability and adverse crop conditions. The objective of this paper is review on effect of moisture or rain fall on crop productivity and production. 


\section{Discussion}

\subsection{Importance of Rain fall}

Among the various individual climatic parameters which influence the growth characteristics of crops and the most important is considered to be water. Limitations in water availability are frequently a restrictive factor in plant development, and water is essential for the maintenance of physiological and chemical processes within the plant, acting as an energy exchanger and carrier of nutrient food supply in solution. In any regional study of agricultural production rainfall is therefore of fundamental importance(Doorenbos and Kassam 1979). As study by Schulze et al. (1997) show that Focus is invariably on the patterns of rainfall in time and over an area, by asking initially

- how much it rains where it rains (its spatial distribution)

- when it rains (its seasonal distribution)

- how frequently it rains and

- What the duration and intensity of rainfall events are.

The reservoir of water from which crops draw their moisture supply through the soil is derived mainly in the form of rainfall, with relatively minor contributions in southern Africa from dew, fog and snow. Not all rainfall is, however, freely available to the crop through the soil, as some is intercepted by the plant before reaching the soil, part runs into streams as storm flow after rainfall events (without being utilized by plants), some percolates into the deeper soil layers beyond the root zones and a portion is evaporated directly from the soil surface without being transpired through the plant(Schulze et al., 1997).

\subsubsection{Effect of Rain fall on crop production}

In addition to the effect of water deficits on leaf area development and senescence, water stress decreases the rate of net photosynthesis per unit leaf area. The deficits required to influence the rate of net photosynthesis are usually greater than those required to influence leaf elongation (Turner and Begg,1978). As research show the effect of drought on barley showed that, during the vegetative stage, water stress primarily reduced yields by a reduction in light interception arising from smaller leaves. However, for stress during the grain filling phase, yield were reduced almost equally by reduced photosynthesis per unit area arising from leaf senescence.

The effect of water deficits in reducing photosynthesis that reduces stomatal conductance. In holm oak (Quercus ilex) seedlings, hardening increased drought tolerance primarily by reducing osmotic potential and stomatal regulation, improved new root growth capacity and enhanced cell membrane stability(Farooq et al., 2009).Water deficits which are sufficient to close stomata and reduce photosynthesis also decrease dark respiration. In leaves, the decrease in the rate of dark respiration is less than the decrease in photosynthesis (Pagter ,2005). Photorespiration is unaffected by short term water deficits, but will ultimately decrease because of the effects of water deficits on the depletion of the substrates for photorespiration (Troughton and slatyer, 1969).

\subsubsection{Effect of Rain fall distribution on crop}

The annual rainfall distribution in the central and northern highlands of Ethiopia, including those areas periodically affected by drought, is generally bimodal (FAO, 1984).

One of the factors affecting crop production is wrong timing of the planting regime due to rainfall variability as a result of global warming effects (Ugochukwuetal., 2000). The successive crop production depends not only on the total, seasonal and annual rainfall but also on proper distribution of rainfall (Igbekele, 1975).

One of the ways of manipulating the climatic factor is the adequate knowledge of optimal planting dates so as to accurately synchronize rainfall incidences with agricultural calendar of crops. Rainfall records monitored by the meteorological unit of the Institute of Agricultural Research and Training Ibadan, Nigeria, showed that rainfall pattern in the forest savannah eco-climatic (rainforest region in the last 15 years but due to human activities have been turned to secondary re growth having some characteristics of savanna region) region have been characterized by instability( Ugochukwuetal., 2000). This instability is expected to have impact on the growth and yield pattern of agricultural crops most of which are rainfall dependent.

\subsubsection{Rain fall amount on crop}

The amount of rainfall, its distribution in a given season is critical in affecting crop growth and its production. Uneven seasonal distribution of rainfall can expose crops to different degrees of dry spells without significant reductions in total rainfall (Barron et al., 2003). Rainfall is often expressed in millimetres per day ( $\mathrm{mm} /$ day) which represents the total depth of rainwater $(\mathrm{mm})$, during 24 hours. It is the sum of all the rain showers which occurred during these 24 hours.

\subsubsection{Rain fall Intensity on crop}

The rainfall intensity is the depth of water (in $\mathrm{mm}$ ) received during a shower divided by the duration of the shower (in hours). It is expressed in millimeters of water depth per hour ( $\mathrm{mm} / \mathrm{hour}$ ). The high intensity shower is less profitable to the crops. The high intensity rainfall usually has big drops that fall with more force on the soil surface (Simane and Struick1,993). In fine textured soil especially, the soil aggregates break down rapidly into 
fine particles that seal the soil surface. The infiltration is then reduced and surface runoff increases. The low intensity rainfall has finer drops. The soil surface is not sealed, the rainwater infiltrates more easily and surface runoff is limited.

\subsubsection{Effective Rain fall}

Effective rainfall is the total rainfall minus runoff minus evaporation and minus deep percolation; only the water retained in the root zone can be used by the plants, and represents what is called the effective part of the rainwater. The term effective rainfall is used to define this fraction of the total amount of rainwater useful for meeting the water need of the crops(Walter, 1967).

When rain water falls on the soil surface, some of it infiltrates into the soil, some stagnates on the surface, while some flows over the surface as runoff. When the rainfall stops, some of the water stagnating on the surface evaporates to the atmosphere, while the rest slowly infiltrates into the soil. From all the water that infiltrates into the soil and some percolates below the root zone, while the rest remains stored in the root zone (Champolivier et al., 1996).

\section{Rain fall season}

In Ethiopia there are three seasons, based on climatological means of rainfall and temperature. These seasons are locally known as Bega, Belg and Kiremt (Gissila et al., 2004).

\subsection{Summer(June to September)}

Crops, harvested September-December, make up the bulk of food production $(90 \%-95 \%)$. The early and late growing periods of the main cropping season (Meher) were always prone to moisture stress while the relatively potential and plain parts of the district experienced water logging with the rain falling in the middle of the season[1].

\subsection{Winter (October to January)}

Bega is the season characterized by cold, sunny and dry weather condition with sometimes, unseasonal rainfall for northern half of the country, and extends from October to January. On the other hand, it is a second rainy season for southern and southeastern lowlands of the country.

During the month of Nov 2013, Amhara, Tigray, Benishangul- gumuze, Gambella, SNNPR, Oromia, Dire Dawa, Harari, Somali and western parts of the country received light to heavy rainfall. The situation might have caused shattering of seed of ripe crops, harvest and post-harvest activities and damage crops at different phases of growth particularly in areas where heavy falls experienced. On the other hand dry, sunny and windy Bega weather condition associated with night and early morning cooling effect caused minimum temperature fallen below $5{ }^{\circ} \mathrm{C}$ which might have negative impact on normal growth of crops not fully attend maturity as well as physiological activities( Haile, 2007)

\subsection{Autumn (February to May)}

Belg is the short rainy season, which extends February-May, and production during this time typically accounts for only $5 \%-10 \%$ of total annual production (CSA 2001).

Belg season - may be hoping good extension of early season rainfall - would often harvest something which might only be better than nothing. Such lack of rain over the Belg season results in poorly fed animals. This reduces available draught power and leads to lowly priced animals. Insufficient rain in the Belg season also pegs the livelihoods of the rural community to the yields of the Meher or the main cropping season(USAID 2003).

The delayed onset of the Meher rain, on its part, would waste the labor power employed to prepare the farmlands. The seeds sown with dry planting would be lost. Moreover, draught power would be limited for the activities to be carried out in June - July as the oxen are poorly fed and weak. This delay would also result in substitution of highly preferred sorghum with less favored crops, such as Tef, and pulses. Sorghum is a major staple food crop and its absence in the production system increases the dependence of the community on the market(Girma et al., 2013).

\section{Mechanism of crop adaptation}

In the natural habitat, the plants adapt to water deficit situation in the microclimate by wide range of mechanisms, ranging from array of morphological, physiological, and biochemical adaptations, as well as varies from transient responses to low soil moisture to major survival mechanisms of escape by early flowering in absence of seasonal rainfall (Bohnert et al., 1995; Basu et al., 2016). Phenological adjustment to escape from the moisture stress duration is most successful in $\mathrm{C} 3$ cereals such as wheat or barley which experiences early terminal drought areas (Lopes et al., 2011).

The plant species tolerant to water logging can develop some morphological traits or can alter the metabolism in response to oxygen shortage to survive or to maintain their growth. The mechanisms of water logging or hypoxia tolerance includes: i) the maintenance of high internal aeration through constitutive aerenchyma and creation of an oxidized zone around root tips through radial $\mathrm{O}_{2}$ loss (Armstrong et al., 1994), ii) metabolic adaptation that maintain energy production under hypoxia with the substantial storage of 
carbohydrates for fermentation under hypoxia (Brandle, 1991).

\subsection{Aerenchyma formation and increased root porosity}

Aerenchyma is a special tissue which consists of continuous gas filled channels or much enlarged gas spaces, and root porosity is volume of gas-filled spaces in relation to the total tissue volume. Aerenchyma provides a low resistance internal pathway for the movement of $\mathrm{O}_{2}$ from the shoots to the roots (Armstrong and Webb, 1985; Drew et al., 1985).

Aerenchyma tissue in roots allows the roots to respire aerobically and to maintain growth under hypoxic conditions. Moreover, a part of oxygen transported to plant root tips through the aerenchyma leaks out into the surrounding soil and results in a small zone of oxygenated soil around the roots providing an aerobic environment for microorganisms that can prevent the influx of potentially toxic soil components (Armstrong 1988; Colmer, 2003) such as nitrites and sulphides of $\mathrm{Fe}, \mathrm{Cu}$ and $\mathrm{Mn}$. Therefore, aerenchyma formation is thought to be one of the most important morphological adaptations for the tolerance to hypoxic or anoxic stress.

\subsection{Metabolic adaptation}

The metabolic adaptations to oxygen deficiency includes: anaerobic respiration, maintenance of carbohydrate supply for anaerobic respiration, avoidance of cytoplasmic acidification and development of anti-oxidative defense system (Davies, 1980; Armstrong et al., 1994; Drew, 1997).

Plant cells produce energy in presence of oxygen through aerobic respiration which includes glycolysis, TCA or Krebs cycle and oxidative phosphorylation. In absence of oxygen (under anoxic condition), Krebs cycle and oxidative phosphorylation are blocked, and cells inevitably undergo anaerobic respiration to fulfill the demand for energy (Davies, 1980). Anaerobic respiration includes glycolysis and fermentation. Generation of energy under anaerobic condition is largely achieved through glycolysis. For the continued operation of glycolytic pathway, the regeneration of $\mathrm{NAD}^{+}$, a cofactor from NADH is essential (Drew, 1997).

Despite the complexity of drought resistance, plant breeders in semi-arid and arid regions of the world have improved the performance of crops and pastures for these regions. While this has usually been achieved by breeding for improved yield or quality under conditions of water shortage, plant physiologists have assisted in this process by identifying mechanisms underlying resistance mechanisms and assisting in the development of selection techniques (Whanet al. 1993).

The yield of these lines was 3-11\% better than the unselected cultivars at dry sites and in dry seasons, but as expected these lines showed no yield reduction at wet sites and in wet seasons (Richards and Passioura1989).

Other characteristics that have been identified and selected in wheat are high assimilate transfer to the grain and rapid grain growth (Turner and Nicolas 1987; Whan et al. 1993). They have been shown to contribute to improved yields under water-limited conditions (Whan et al. 1993).

\subsection{Morphological mechanisms of adaptation to moisture deficits.}

An important consequence of this reduction in leaf area is the associated reduction in water loss, thereby reducing the rate of water use and delaying the onset of more severe stress(Mitra, 2001 ).

Hall et al. (1979) have argued that leaf senescence in cereals could confer an adaptive advantage if it were accompanied by a substantial reduction in transpiration, as the older lower leaves which senesce first are supplying relatively little carbohydrate to the developing grain. Hurd (1974) showed that deeper rooting varieties yield better under drought stress.

Alternatively, for situations in which soil water is not available at depth and plants have to survive on limited resources of stored water near the surface, the hydraulic conductance of roots could be decreased.

\subsection{Physiological mechanisms of adaptation to moisture deficits}

A range of physiological mechanisms enables plants to adapt to stress: (i) seed priming, (ii) stomata control of water loss, (iii) osmotic adjustment. Henkel (1961) and Henckel (1964) proposed a method of increasing the resistance to dehydration by treating the seed before it was sown: the treatment involved allowing the seed to take up water to 30 per cent dry weight, then leaving at $10 \sim$ to $25 \sim$ for 24 hrs followed by air drying.

As demonstrated by Shimshi (1963), stomata closure can decrease transpiration and increase the efficiency of water use. This has led to several attempts to screen for higher resistance to water loss in crop plants, either by screening for low stomata frequency or for high stomata.

The significance of osmotic adjustment is that it helps to maintain positive turgor as water deficits develop (Turner and Jones, 1980). This enables the plant to maintain leaf expansion and photosynthetic activity at levels of stress which are not possible in its absence (Steponkus et al., 1980). Moreover, it should enable plants to deplete the soil water to a lower soil water potential and allow a greater exploration of soil by roots the additional water made available by decreasing the soil water potential is likely to be small but the additional water available from the exploration of a greater soil volume could be significant (Jordan and Miller, 1980). 
Recent evidence suggests that osmotic adjustment may have an effect on yield beyond that directly attributable to increased assimilation has produced evidence that suggests that abscisic acid produced in the leaves at low turgor pressures reduces seed set of wheat through its effects on pollen viability. The maintenance of turgor by osmotic adjustment of the leaves may thereby have a significant effect on yield by reducing the production of abscisic acid and maintaining pollen viability (Morgan, 1980).

\subsubsection{Drought escape}

The ability of a crop plant to complete its life cycle before development of serious soil and plant water deficits is called as drought escape. This mechanism involves rapid phenological development i.e. early flowering and maturity, variation in duration of growth period depending on the extent of water scarcity. For instance, in cow pea early erect cultivars, such as "Ein El Gazal"e and "Melakh"e, have performed well when the rainfall season was short but distinct due to their ability to escape late-season drought (Hall, 2004).

\subsubsection{Drought avoidance}

Drought avoidance is the ability of plants to maintain relatively high tissue water potential despite a shortage of soil moisture. Improving the mechanisms of water uptake, storing in plant cell and reducing water loss confer drought avoidance. Drought avoidance mechanisms are associated with physiological whole-plant mechanisms such as canopy tolerance and leaf area reduction (which decrease radiation, adsorption and transpiration), stomatal closure and cuticular wax formation, and adjustments of sink-source relationships through altering root depth and density, root hair development and root hydraulic conductance (Rivero et al. 2007).

\subsubsection{Drought tolerance}

The ability of a crop to endure moisture deficits at low tissue water potential or dehydration tolerance (Levitt,1972). Drought tolerance mechanisms are balancing of turgor through osmotic adjustment (solute accumulation in cell), increase in elasticity in cell but decrease in cell size and desiccation tolerance by protoplasmic tolerance (Ugherughe, 1986). Most of drought adaptations have disadvantages as the genotypes of short duration are less productive compared to that of normal duration. The drought tolerance mechanisms conferred by reducing water loss (such as stomatal closure and reduced leaf area) usually result in reduction of assimilation of carbon dioxide (Mitra, 2001). Drought tolerance can be increased through osmotic adjustment by maintaining plant turgor, but the increased solute concentration responsible for osmotic adjustment may have detrimental effect in addition to energy requirement for osmotic regulation (Turner, 1979). Therefore, crop adaptations to drought may be established through a balance between escape, avoidance and tolerance while maintaining adequate productivity.

\subsection{Developmental mechanisms of Crop adaptation to moisture deficits}

Partial dormancy is another means through which some plants survive drought, as observed in Retama raetam, (a stem-assimilating, C3, evergreen desert legume common to arid ecosystems). From acclimation studies Mittler et al., (2001) A pattern of phenological development that allows a crop to complete its lifecycle without having to face a serious water deficit would clearly be advantageous in a dry environment. The so-called desert ephemerals have a number of adaptations that enable them to do this: germination inhibitors that inhibit germination until the first soaking rain, rapid phenological development after germination and phenological plasticity that enables them to set many seeds in a year with little rainfall (Mulroy and Rundle, 1977).

\section{Future Prospective}

Appropriate management and utilization, has a potential to serve as an adaptation strategy to current rainfall variability and crop production by enabling production of high market value crops with implications for adaptation to future climate change as well.

\section{Conclusion}

Plant growth and crop yield are closely related to the amount of moisture available during the growing season. The impact of rainfall on crop production can be related to its total seasonal amount or its intra-seasonal distribution. In the extreme case of droughts, with very low total seasonal amounts, crop production suffers the most.

The Effect of rainfall on crop production trends is that projected food shortages in Ethiopia may soon pass beyond chronic into tragic, exceeding the ability of food aid to make up the difference. Appropriate management and utilization, has a potential to serve as an adaptation strategy to current rainfall variability and supplement rain fed crop production by enabling production of high market value crops with implications for adaptation to future climate change as well.

\section{Reference}

Adugna.L, 2005.Rainfall Probability and Agricultural Yield in Ethiopia.

Armstrong W, Webb T (1985) A critical oxygen pressure for root extension in rice. J Exp Bot 36: 1573-1582 
Barron, J., J. Rockström, F. Gichuki, and N. Hatibu. (2003) "Dry Spell Analysis and Maize Yields for Two Semiarid Locations in East Africa." Agricultural and Forest Meteorology 117 (1-2): 23-37.

Basu, S., Ramegowda, V., Kumar, A. and Pereira, A. (2016) Plant adaptation to drought stress [version 1; referees: 3 approved] F1000Research 2016, 5(F1000 Faculty Rev):1554 (doi: 10.12688/f1000research.7678.1)

Brandle RA (1991) Flooding resistance of rhizomatous amphibious plants. In: Jackson MD, Davies DD, Lambers H (eds) Plant life under oxygen deprivation. Academic Publisher, The Hague. pp 35-46.

Bohnert, H.J., Nelson, D.E., Jensen, R.G. (1995) Adaptations to Environmental Stresses. Plant Cell, 7(7): 1099111.

Champolivier, L. and A. Merrien. (1996) Effect of water stress applied at different growth stages to Brassica napus L. var Oleifera on yield components and seed quality. Eur. J. Agron. 5:153-160.

Colmer TD (2003) Long-distance transport of gases in plants: a perspective on internal aeration and radial oxygen loss from roots. Plant Cell Environ 26:17-36 C

CSA (Central Statistical Agency) (2001). Report on Area and Production of Major Crops: Private Peasant Holdings, Meher Season. Agricultural Sample Survey 2001 /2, Volume 1, Addis Ababa, Ethiopia.

Doorenbos J and Kassam A H. (1979). Yield response to water. FAO Irrigation and Drainage Paper No. 33, FAO, Rome.

Farooq M., Wahid A., Kobayashi N., Fujita D., and Basra S.M.A. (2009) Plant drought stress: effects, mechanisms and management. Agronomy for Sustainable Development, Springer Verlag/EDP Sciences/INRA, 29 (1), pp.185-212. <hal-00886451>

Fischer. G, M. Shah, and H. van Velthuizen. (2002) Climate Change and Agricultural Vulnerability. Special report for the UN World Summit on Sustainable Development, 26 August-4 September, Johannesburg. Laxenburg, Austria: International Institute for Applied Systems Analysis. [www.iiasa.ac.at/Research/LUC/JB-Report.pdf ].

FAO(1984) Agroclimatic resources inventory for land-use planning, based on the work of Victor Odenyo and Wolfgang Goebel. In: Assistance to land-use planning, Ethiopia.

Girma T. K, Debrah .M, Simon .G, Bezabih .E(2013)Efficiency of moisture stress risk coping strategies in North Eastern Ethiopia: application of mean-variance efficiency analysis. Asian Economic and Financial Review, 2013, pp 103-118

Gissila, T., E. Black, D. I. F. Grimes, and J. M. Slingo, (2004) Seasonal forecasting of the Ethiopian summer rains. Int. J. Climatol., 24, 1345-1358.

Haile, N.(2007) An Economic Analysis of Farmers' Risk Attitudes and Farm Households' Responses to Rainfall Risk in Tigray, Northern Ethiopia. PhD thesis, Mansholt Graduate School of Social Sciences, Wageninger University, the Netherlands.

Hall, A.E. (2004): Breeding for adaptation to drought and heat in cowpea. European J. Agron., 21: 447-454

Hall, A. E., Foster, K. W. and Waines, J.G. (1979) Crop adaption in semi-arid environments. In: Hall, A. E., Canell, G. H. and Lawton, H. W. (eds.), Agriculture in semi-arid environments, pp. 148-79. SpringerVerlag, Berlin.

Henckel, P.A. (1964) Physiology of plants under drought. Annu. Rev. Plant Physiol. 15, 363-86.

Henkel, P. A. (1961) Drought resistance in plants: methods of recognition and of intensification. In Plant-water relationships in arid and semi-arid conditions. Proc. Madrid. Symp., 1959, pp. 167-74.UNESCO, Paris.

Hurd, E. A. (1974) Phenotype and drought tolerance in wheat. Agric Meteorol. 14, 39-55.

Igbekele JO (1975). Crop - Climate Relationship in Western Nigerian. Niger. Geogr. J. 5: (1)21 -32.

Jordan, W. R. and Miller, F. R. (1980) Genetic variability in sorghum root systems: implications for drought tolerance. In: Turner, N. C. and Kramer, P. J. (eds.), Adaption of plants to water and high temperature stress, pp. 383-99. Wiley Inter science,

Levitt, J.B. (1972): Responses of plants to environmental stresses. Academic Press, New York.

Lopes M. S., Araus J. L., Van Heerdeen P.D.R and Foyer C. H. (2011). Enhancing Drought Tolerance in C4 Crops. Journal of Experimental Botany, 62(9), 3135-3153

Mitra J. (2001). Genetics and Genetic Improvement of Drought Resistance in Crop Plants. Current Science,80(6), 758-763.

Mittler R., Merquiol E., Hallak-Herr E., Rachmilevitch S., Kaplan A., and Cohen M. (2001). Living Under a Dormant Canopy: a Molecular Acclimation Mechanism of the Desert Plant Retama raetam. The Plant Journal, 25, 407-416.

Morgan, J. M. (1980) Differences in adaption to water stress within crop species. In: Turner, N. C. and Kramer, P. J. (eds.), Adaption of'plants to water and high temperature stress, pp. 369-382. Wiley Interscience, New York.

Mulroy, T.W. and Rundel, P.W. (1977) Annual plants; adaption to desert environments. Bio Science 27, 109-14.

National Meteorological Agency (2013/14 ) Agrometeorological bulletin, seasonal agrometeorological bulletin 
bega, volume 25. no.3

Pagter M, Bragato C, Brix H (2005) Tolerance and physiological responses of Phragmites australis to water deficit. Aquat Bot 81:285-299

Rivero, R.M., Kojima, M., Gepstein, A., Sakakibara, H., Mittler, R., Gepstein, S. and Blumwald, E. (2007): Delayed leaf senescence induces extreme drought tolerance in a flowering plant. Proceedings of National AcademicScience U.S.A. 104:19631-19636.

Schulze, Maharaj, Lynch, Howe and Melvil-Thompson, (1997)"South African Atlas of Agrohydrology and Climatology", WRC,

Shimshi, D. (1963) Effect of soil moisture and phenylmercuric acetate upon stomatal aperture, transpiration, and photosynthesis. Plant.Physiol. 38, 71321.

Simane B and Struik P C (1993) Agroclimatic analysis: a tool for planning sustainable durum wheat (Triticum turgidum var. durum) production in Ethiopia. Agric. Ecosyst. Environ. (In press).

Sivakumar, M. V. K. Empirical Analysis of Dry Spells for Agricultural Applications in West Africa International Crops Research Institutefor the Semi-Arid Tropics (ICMAT) Sahelian Center, Niamey, Niger

Steponkus, P. L., Cutler, J. M. and O'Toole, J.C. (1980) Adaptation to water stress in rice. In: Turner, N. C. and Kramer, P. J (eds.), Adaptation of plants to water and high temperature stress, pp. 401-18. Wiley Interscience, New York.

Tesfahun, G., B. Emana and N. Abdoulaye, (2006).Managing moisture stress risk to copewith food insecurity in kalu district. North Eastern Ethiopia AgriculturalEconomics Journal of Ethiopia, 6(1): 17-34.

Troughton, J. H. and Slatyer, R. O. (1969) Plant water status, leaf temperature, and calculated mesophyll resistance to carbon dioxide of cotton leaves. Aust. J. Biol. Sci. 22, 815-27.

Turner, N. C. and Begg, J.E. (1978) Responses of pasture plants to water deficits. In: Wilson, J. R. (ed.), Plant relations in pastures, pp. 50-66. CSIRO, Melbourne.

Turner NC (1979) Stress Physiology in Crop Plants. In Mussell H and Staples RC) (eds.). Wiley, New York, pp. $343-372$

Turner, N. C. and Jones, M. M.(1980) Turgor maintenance by osmotic adjustment: a review andevaluation. In: Turner, N. C. and Kramer, P. J. (eds.), Adaptation of plants to water and hightemperature stress, pp. 87-103. Wiley Interscience, New York.

Ugochukwu OC, Otegbade JO, Patrick I, Okeke EU, Suleiman AI (2000). STAN Agricultural Science for Senior Secondary Schools, p. 457

Ugherughe, P.O. (1986): Drought and tropical pasture management. Z. Acker-u. Pflanzenbau.J. Agron. Crop Sci.,157: 13-23.

USAID(2003). United States Agency For International Development.

Vste, E., DribaKorcha and Asgeir Sorteberg, (2013).Recent drought and precipitation tendencies in Ethiopia. TheorApplClimatol (2013)Springer-Verlag, p. 535-551

Walter MW (1967). Length of Rainy Season in Nigeria. Niger. Geogr. J. 8: 123 - 126.

Whan, B.R., Siddique K.H.M., Regan K.L. and Turner N.C.(1993) Integration of Breeding and Physiology: Lessons from a Water-Limited Environment. Queensland wheat research Institute Toowoomba, Queensland Australia.

Woldemariam, M. (1991), Suffering Under God's Environment: A Vertical Predicament of Peasants in Northcentral Ethiopia, Walsworth Publishing Company, Missouri.

Zeleke, G., W. Bewket and Alemu .D, (2010) Economics of adaptation to climate change: Ethiopia case study learning from past experiences with extreme climate events Final Draft of World Bank Consultation Report, Addis Ababa, Ethiopia. 